\title{
Germination response of Hylocereus setaceus (Salm-Dyck ex DC.) Ralf Bauer (Cactaceae) seeds to temperature and reduced water potentials
}

\author{
Simão, E. a Takaki, M. ${ }^{\mathrm{b}}$ and Cardoso, VJM. ${ }^{\mathrm{b} *}$ \\ aFundação de Ensino e Pesquisa de Itajubá, Av. Dr. Antônio Braga Filho, 897, \\ CEP 37501-002, Itajuba, MG, Brazil \\ 'Departamento de Botânica, Instituto de Biociências, Universidade Estadual Paulista - UNESP, \\ CP 199, CEP 13506-900, Rio Claro, SP, Brazil \\ *e-mail: victorjc@rc.unesp.br \\ Received June 30, 2008 - Accepted August 21, 2008 - Distributed February 28, 2010
}

(With 4 figures)

\begin{abstract}
The germination response of Hylocereus setaceus seeds to isothermic incubation at different water potentials was analysed by using the thermal time and hydrotime models, aiming to describe some germination parameters of the population and to test the validity of the models to describe the response of the seeds to temperature and water potential. Hylocereus setaceus seeds germinated relatively well in a wide range of temperatures and the germination was rate limited from 11 to $20^{\circ} \mathrm{C}$ interval and beyond $30^{\circ} \mathrm{C}$ until $40{ }^{\circ} \mathrm{C}$, in which the germination rate respectively shifts positively and negatively with temperature. The minimum or base temperature $\left(\mathrm{T}_{\mathrm{b}}\right)$ for the germination of $H$. setaceus was $7{ }^{\circ} \mathrm{C}$, and the ceiling temperature varied nearly from 43.5 to $59{ }^{\circ} \mathrm{C}$ depending on the percent fraction, with median set on $49.8{ }^{\circ} \mathrm{C}$. The number of degrees day necessary for $50 \%$ of the seeds to germinate in the infra-optimum temperature range was $39.3{ }^{\circ} \mathrm{C}$ day, whereas at the supra-optimum interval the value of $\theta=77$ was assumed to be constant throughout. Germination was sensitive to decreasing values of $\Psi$ in the medium, and both the germinability and the germination rate shift negatively with the reduction of $\Psi$, but the rate of reduction changed with temperature. The values of base water potential $\left(\Psi_{\mathrm{b}}\right)$ shift to zero with increasing temperatures and such variation reflects in the relatively greater effect of low $\Psi$ on germination in supra optimum range of T. In general, the model described better the germination time courses at lower than at higher water potentials. The analysis also suggest that $\mathrm{T}_{\mathrm{b}}$ may not be independent of $\Psi$ and that $\Psi_{\mathrm{b}(\mathrm{g})}$ may change as a function of temperature at the infra-otimum temperature range.
\end{abstract}

Keywords: Cactaceae, Hylocereus, hydrotime, thermal time, water potential.

\section{Resposta de germinação das sementes de Hylocereus setaceus (Salm-Dyck ex DC.) Ralf Bauer (Cactaceae) à temperatura e à redução do potencial de água}

\begin{abstract}
Resumo
As respostas de germinação de sementes de Hylocereus setaceus para incubações isotérmicas sob diferentes potenciais de água foram analisadas utilizando-se modelos de graus dia e psi dia, com o objetivo de descrever alguns parâmetros da população e para testar a viabilidade do modelo para descrever as respostas da semente a temperatura e potencial de água. Sementes de $H$. setaceus germinaram relativamente bem em uma ampla faixa de temperaturas e a germinação foi limitada pela velocidade nos intervalos de 11 a $20{ }^{\circ} \mathrm{C}$, e de 30 até $40{ }^{\circ} \mathrm{C}$, nos quais a velocidade de germinação aumenta e diminui, respectivamente, com a temperatura. A temperatura mínima ou base $\left(\mathrm{T}_{\mathrm{b}}\right)$ para germinação de H. setaceus foi $7{ }^{\circ} \mathrm{C}$, e a temperatura máxima variou de 43,5 a $59{ }^{\circ} \mathrm{C}$ dependendo da fração percentual, com média de $49,8^{\circ} \mathrm{C}$. O número de graus dia necessário para $50 \%$ das sementes germinarem na faixa de temperatura infra-ótima foi de $39,3{ }^{\circ} \mathrm{C}$ dia, enquanto que, no intervalo supra-ótimo o valor de $77^{\circ} \mathrm{C}$ dia foi assumido como constante para todo o intervalo. A germinação foi sensível à diminuição do $\Psi$ no meio, e tanto a germinabilidade como a velocidade de germinação mudaram negativamente com a redução do $\Psi$, sendo que a taxa de redução mudou com a temperatura. Os potenciais base de água $\left(\Psi_{\mathrm{b}(\mathrm{g})}\right)$ tendem a zero com o aumento da temperatura e essa variação se reflete no efeito relativamente maior do $\Psi$ sobre a germinação na faixa supra-ótima de temperatura. No geral, o modelo descreveu melhor as curvas de germinação em potenciais de água baixos do que em altos. As análises também sugerem que $\mathrm{T}_{\mathrm{b}}$ pode não depender do $\Psi$ e que o $\Psi_{\mathrm{b}(\mathrm{g})}$ pode mudar em função da temperatura na faixa infra-ótima de temperatura.
\end{abstract}

Palavras-chave: Cactaceae, Hylocereus, psi dia, graus dia, potencial da água. 


\section{Introduction}

Successful establishment of plant species in a natural environment can be related to timing for germination resulting from seed response to environmental factors such as water availability, light and temperature. In Medicago sativa L. (alfafa), for example, rapid germination and primary root growth at infra-optimal temperatures in the laboratory was positively correlated with high emergence at field conditions (Klos and Brummer, 2000). Thus, germination cueing determines a particular set of environmental conditions that a germinant will encounter (Donohue, 2005) and seeds often respond to combinations of environmental factors that are most favourable to the seedling growth and survival (Simao et al., 2007; De La Barrera and Nobel, 2003)

Temperature is a very important factor controlling seed germination, affecting both the rate and final percentage of germination. Studies on temperature-dependent seed germination have taken into account cardinal temperatures, that is, the base or minimum temperature $\left(\mathrm{T}_{\mathrm{b}}\right)$ below which seeds will not germinate, an optimal temperature $\left(\mathrm{T}_{\mathrm{o}}\right)$ at which the best germination is attained, and a maximum or ceiling temperature $\left(\mathrm{T}_{\mathrm{c}}\right)$ above which no germination occurs (Labouriau, 1983). Within a given range, only the germination rate (the reciprocal of the time taken for the germination) is affected by temperature and such germination rate dependency on temperature may be one of the most important factors controlling the emergence timing in the field, thus influencing the probability of seedling establishment (Washitani, 1985). Seeds do not respond simultaneously to temperature but germination is rather spread over time due to intrinsic characteristics of each seed. A valuable tool for analysing the spread of the germination rate was proposed by Garcia-Huidobro et al. (1982) based on the assumption that the order in which seeds germinate is independent of temperature, and each seed can be assigned a value of $\mathrm{g}_{\%}$ (a germination fraction at which it germinates) that can be used to identify each seed or small group of seeds sharing an identical $g_{\%}$ or germination rate (reciprocal of the time to germination of the fraction $\mathrm{g}_{\%}$ ) (Gummerson, 1986). Thus, all the seeds of each fraction are assumed to germinate at the same time, and the fractions can be discriminated from each other by particular cumulative percentages at which they germinate (Washitani, 1985). The application of the model is based on the observation that there is a temperature range over which the germination rate for a given fraction $\mathrm{g}_{\%}$ increases linearly with the temperature according to the equation: $1 / \mathrm{t}_{\mathrm{g}}=\left(\mathrm{T}-\mathrm{T}_{\mathrm{b}}\right) / \theta_{\mathrm{g}}$, where $\mathrm{t}_{\mathrm{g}}$ is the time to germination of the fraction $g_{\%}, T$ is the actual temperature and $\theta_{g}$ is the "thermal time", which is followed by the notation $g$ to indicate that it varies from seed to seed. If all the seeds in a population germinated at the same time, the germination time course would be a step function and the time to germination of different fractions would be constant. The variation in the time to germination accounts for the sigmoid shape of the germination time curve and must be caused by the seeds having different thermal time requirements (Gummerson, 1986). At supra-optimal temperatures, however, the germination rate decreases with temperature and it is the $\mathrm{T}_{\mathrm{c}}$ that varies among fractions while the thermal time to radicle protrusion is a constant for all seeds. Thus, in the supra-optimal temperature range the following thermal time equation must be used (Garcia-Huidobro et al., 1982): $1 / \mathrm{Tc}_{(\mathrm{g})}=\left(\mathrm{T}-\mathrm{T}_{\mathrm{c}}\right) / \theta$. For seeds, the thermal time represents the progress toward germination and it can give a good estimate of the time to emergence for specific crops.

Regardless of the temperature, germination can be delayed or prevented if there is insufficient water within the seed to generate the turgescence pressure required for cell expansion, thus seed germination is highly dependent on the water potential $(\Psi)$ in the substrate (Bradford and Still, 2004). Gummerson (1986) proposed that seed germination responses to $\Psi$ could be described on a "hydrotime" scale similar to the thermal time one, and many authors have analysed the effect of $\Psi$ on seed germination in a manner analogous to that. Gummerson (1986) defined a hydrotime constant as $\theta_{\mathrm{H}}=\left(\psi-\psi_{\mathrm{b}(\mathrm{g})}\right) \mathrm{t}_{\mathrm{g}}$, where $\psi_{\mathrm{b}(\mathrm{g})}$ is the threshold or base $\Psi$ that will just prevent germination of fraction g. Considering $\theta_{\mathrm{H}}$ as constant, the time required for a percentage $\mathrm{g}$ to germinate is inversely proportional to the difference between the medium $\Psi$ and the $\Psi_{\mathrm{b}}$ of the respective fraction $\mathrm{g}$. Within a seed population, the normal distribution of $\Psi_{\mathrm{b}}$ values among seeds accounts for the variation in $\theta_{\mathrm{g}}$ among different seed fractions. In other words, the distribution of $\Psi_{b(g)}$ values results in a characteristic sigmoid cumulative time course of germination events (Bradford, 1997). Thus, the thermal and hydrotime models can also be combined to result in a hydrothermal time model according to the equation: $\theta_{\mathrm{HT}}=\left(\mathrm{T}-\mathrm{T}_{\mathrm{b}}\right)\left(\Psi-\Psi_{\mathrm{b}(\mathrm{g})}\right) \mathrm{t}_{\mathrm{g}}$, where $\theta_{\mathrm{HT}}$ is the hydrothermal time constant ( $\mathrm{MPa}{ }^{\circ} \mathrm{C}$ time). This equation is useful to describe germination time courses at any combination of sub-optimal temperature and $\Psi$ (Bradford, 1995), whereas a modified hydrothermal time model was proposed by Alvarado and Bradford (2002) to describe the germination timing and percentages across temperatures and $\Psi$ at the supra-optimum temperature range.

Hylocereus setaceus (Salm-Dyck ex DC.) Ralf Bauer, commonly known as dragon fruit, strawberry pear and pitaya, is an epiphytic cactus, stems usually climbing on trees, sometimes clambering over rocks or walls, developing many aerial roots. Widespread in eastern Brazil from northern Piauí southwards; northern, central-western and southern Brazil (southern Pará southwards to Mato Grosso do Sul and Paraná); and South America (southwards to east Bolivia, north Argentina and Paraguay) (Britton and Rose, 1937). Seeds of H. setaceus are highly sensitive to light and germinate in a relatively wide range of temperature (Simão et al., 2007). Considering that the thermal and hydrotime approach can be used for expressing the relationship between temperature, water 
potential and germination, and considering the gap in the scientific literature on thermal time analysis of germination of Cactaceae seeds, the aim of this study was to describe some germination parameters of Hylocereus setaceus seeds and to test the validity of the hydrotime model describing the seed germination in response to a range of water potentials and temperatures.

\section{Material And Methods}

Fruits of $H$. setaceus were harvested in December 2004 from three plants, in a fragment of seasonal semidecidual forest located at São Tomás de Aquino, MG, Brazil. The fruits were depulped on a sieve and the seeds were washed under tap water. For the de-pulping process, the $\mathrm{pH}$ of water was decreased with small doses of commercial vinegar $\left(\right.$ BELMONT $\left.^{\circledR}\right)$ and immediately washed with current tap water to remove the pulp firmly adhered to the seeds. After that, the seeds were dried at room temperature (around $25{ }^{\circ} \mathrm{C}$ ) up to five days and stored at $10{ }^{\circ} \mathrm{C}$ in a sealed glass bottle until required (October 2006). The mass of 1000 seeds of the H. setaceus batch used in the experiments was $2.80 \pm 0.0424 \mathrm{mg}$ (Simão et al., 2007).

The assays were carried out in the Plant Photomorphogenesis Laboratory at the Botany Department, IB, Rio Claro, SP, Brazil. The seeds were sown on two layers of filter paper saturated with distilled water or solution, in $50 \mathrm{~mm}$ inner diameter glass Petri dishes, which were put inside colorless plastic boxes (Gerbox). Three replicates per treatment with 40 seeds each were placed in growth cabinets under continuous white light - two $20 \mathrm{~W}$ fluorescent tubes, $32.85 \mu \mathrm{mol} . \mathrm{m}^{-2} / \mathrm{s}$ at seed level - at the constant temperatures of $11,14,17,20,25,30,34,37$ and $40{ }^{\circ} \mathrm{C}\left( \pm 1^{\circ} \mathrm{C}\right)$. In order to control the water potential of the germination medium, different solutions of polyethylene-glycol 6000 (PEG 6000) were prepared according to Villela et al. (1991) that maintained the nominal water potentials of $-0.1,-0.2$ and $-0.35 \mathrm{MPa}$ at the respective temperature. In order to maintain an approximate known $\Psi$ the seeds were transferred to fresh PEG solutions as soon as the blotters appeared to be drying. The germination (radicle protrusion) was scored daily and the germinated seeds were removed.

The germinability (maximum germination) was the accumulated germination percentage recorded up to 30 days from the beginning of the assay. The germination rate was computed as the reciprocal of the time (days) to radicle emergence of an arbitrary percentage or fraction $\mathrm{g}(\mathrm{g}=5,10,20,30,40,50,60,70$ and 80\%), estimated from the actual germination time courses fitted by the Weibull function (Dumur et al., 1990). The average germination rate $(\overline{\mathrm{A}})$ was calculated according to the equation $\bar{A}=\Sigma n_{i} / \Sigma n_{i} \cdot t_{i}$, where $n_{i}$ is the number of germinated seeds at the time interval $t_{i}$ (Labouriau and Agudo, 1987).
The distributions of the cumulative germination percentages were analysed and the parameters were determined for the thermal time, hydrotime and hydrothermal time models. To find the values of base temperature $\left(\mathrm{T}_{\mathrm{b}}\right)$, median thermal time $\left(\theta_{50}\right)$ and standard deviation $\left(\sigma_{\theta}\right)$ of the thermal time distribution, the cumulative daily germination percentages of Hylocereus setaceus seeds kept in distilled water at three temperatures $\left(11,14\right.$ and $\left.17^{\circ} \mathrm{C}\right)$ in the infra-optimum range were transformed to probit and plotted against the respective $\theta_{\mathrm{g}}\left(=\left[\mathrm{T}-\mathrm{T}_{\mathrm{b}}\right] \mathrm{t}_{\mathrm{g}}\right)$ on a logarithmic scale (Bradford, 1995). The data were combined into a common linear regression to determine $\mathrm{T}_{\mathrm{b}}$ according to the model $\operatorname{probit}(\mathrm{g})=\left\{\log \left[\left(\mathrm{T}-\mathrm{T}_{\mathrm{b}}\right) \mathrm{t}_{\mathrm{g}}\right]-\log \theta_{50}\right\} / \sigma_{\theta}$, and repeated regression analyses were performed varying the value of $\mathrm{T}_{\mathrm{b}}$ until the best fit (higher $\mathrm{R}^{2}$ ) was obtained (Bradford, 1995). Then, $\theta_{50}$ is the $\theta$ value ( $\mathrm{x}$ axis) necessary for $50 \%$ of the seeds to germinate $(=5$, on the probit axis), and $\sigma_{\theta}$ is the inverse of the slope of the probit regression line. A similar procedure was used to determine the median ceiling temperatures $\left(\mathrm{Tc}_{50}\right), \sigma_{\mathrm{Tc}}$ and $\theta$, substituting $\left[\left(T-T_{b}\right) t_{g}\right]$ for $\left[T+\theta / t_{g}\right]$ and $\theta_{50}$ for $T c_{50}$ in the model above, with temperatures at the supra-optimum range $\left(34,37\right.$ and $\left.40{ }^{\circ} \mathrm{C}\right)$. Thus, probit $(\mathrm{g})$ data were regressed on $\log \mathrm{T}_{\mathrm{c}}\left(\mathrm{T}_{\mathrm{c}}=\mathrm{T}+\theta / \mathrm{t}_{\mathrm{g}}\right)$ and different values of $\theta$ were tried until the best fit. The median $T_{c}$ is the $T_{c}$ value ( $\mathrm{x}$ axis) corresponding to the fraction $50 \%$ (probit $=5$ on the $\mathrm{y}$ axis), and $\sigma_{\mathrm{Tc}}$ is the inverse of the slope.

The repeated probit analysis technique referred to above was used to estimate the values of $\theta_{\mathrm{H}}$, median $\psi_{\mathrm{b}}(=$ $\left.\psi_{\mathrm{b}(50)}\right)$ and $\sigma_{\psi \beta}$ (the standard deviation of $\psi_{\mathrm{b}}$ among seeds). For the infra-optimum temperatures $\left(11,14\right.$ and $\left.17^{\circ} \mathrm{C}\right)$ the linear model was probit $(\mathrm{g})=\left[\psi-\left(\theta_{\mathrm{H}} / \mathrm{t}_{\mathrm{g}}\right)-\psi_{\mathrm{b}(50)}\right] / \sigma_{\psi \mathrm{b}}$ (Bradford, 1995). Daily cumulative germination percentages at $-0.1,-0.2$ and $-0.35 \mathrm{MPa}$ were combined into a single regression of probit $(\mathrm{g})$ (y axis) as a function of $\psi_{\mathrm{b}(\mathrm{g})}$ $\left(=\psi-\theta_{\mathrm{H}} / \mathrm{t}_{\mathrm{g}}\right)$, and different values of $\theta_{\mathrm{H}}$ were used until the highest $\mathrm{R}^{2}$ was obtained (Bradford, 1995). Median $\psi_{\mathrm{b}}$ is then the midpoint of the regression line (probit $(\mathrm{g})=5)$, and $\sigma_{\psi b}$ is the reciprocal of the slope. One regression was performed for each infra-optimum temperature and the $\psi_{\mathrm{b}(\mathrm{g})}$ distributions were used to generate theoretical germination time courses at each infra-optimal T and $\psi$ combination (Alvarado and Bradford, 2002). Both temperature and $\psi$ responses of germination at the infra-optimum temperature range can also be combined and expressed on a hydrothermal time basis, according to the model $\operatorname{probit}(\mathrm{g})=\left\{\left[\Psi-\theta_{\mathrm{HT}} /\left(\left(\mathrm{T}-\mathrm{T}_{\mathrm{b}}\right) \mathrm{t}_{\mathrm{g}}\right)\right]-\Psi_{\mathrm{b}(50)}\right\} / \sigma_{\Psi \mathrm{b}}$ where $\theta_{\mathrm{HT}}$ is a hydrothermal time constant (Bradford, 1995). The parameters $\theta_{\mathrm{HT}}, \Psi_{\mathrm{b}(50)}$ and $\sigma_{\Psi \mathrm{b}}$ were found by combining the germination time courses at different infra-optimal temperatures and $\psi$ into a single regression of probit $(\mathrm{g})$ on $\left[\Psi-\theta_{\mathrm{HT}} /\left(\left(\mathrm{T}-\mathrm{T}_{\mathrm{b}}\right) \mathrm{t}_{\mathrm{g}}\right)\right]$. Different values of $\theta_{\mathrm{HT}}$ were entered until the best fit, and $\Psi_{\mathrm{b}(50)}$ and $\sigma_{\Psi \mathrm{b}}$ were estimated as above.

For the supra-optimum temperature range the hydrothermal time model was probit $(\mathrm{g})=\left\{\left[\Psi-\mathrm{k}_{\mathrm{T}}\left(\mathrm{T}-\mathrm{T}_{\mathrm{o}}\right)\right]-\left(\theta_{\mathrm{H}} /\right.\right.$ $\left.\left.\mathrm{t}_{\mathrm{g}}\right)-\Psi_{\mathrm{b}(50)}\right\} / \sigma_{\Psi \mathrm{b}}$, where $\mathrm{k}_{\mathrm{T}}$ is the slope of the $\psi_{\mathrm{b}(\mathrm{g})}$ versus $\mathrm{T}$ line when $\mathrm{T}>\mathrm{T}_{\mathrm{o}}$ (optimal temperature) and $\theta_{\mathrm{H}}$ is the 
hydrotime value at $\mathrm{T}_{0}$. Germination time courses of seeds incubated in $-0.1,-0.2$ and $-0.35 \mathrm{MPa}$ at the temperatures of 34,37 and $40{ }^{\circ} \mathrm{C}$ were combined into a single regression of probit $(\mathrm{g})$ on $\left[\Psi-\mathrm{k}_{\mathrm{T}}\left(\mathrm{T}-\mathrm{T}_{\mathrm{o}}\right)-\theta_{\mathrm{H}} / \mathrm{t}_{\mathrm{g}}\right]$. Following Alvarado and Bradford (2002), this model was fitted by changing systematically $\mathrm{T}_{\mathrm{o}}, \mathrm{k}_{\mathrm{T}}$ and $\theta_{\mathrm{H}}$ until the median $\psi_{\mathrm{b}}$ for this model was equal to the $\psi_{\mathrm{b}(50)}$ of the hydrothermal time model at the infra-optimum temperature range. Note that this model stops the accumulation of thermal time at the value equivalent to that accumulated at $T_{\text {o }}$. Thus, temperatures above $\mathrm{T}_{\mathrm{o}}$ do not add thermal time in the supra-optimal range; and effects on germination are accounted for by the change in $\psi_{\mathrm{b}(\mathrm{g})}$ (Bradford, 1995). The hydrotime parameters at the temperatures of 34,37 and $40{ }^{\circ} \mathrm{C}$ were derived by fitting the combined $\psi$ data at each temperature using the common $\theta_{\mathrm{H}}$ obtained through the supra-optimal hydrothermal time model (Alvarado and Bradford, 2002). The $\psi_{\mathrm{b}(\mathrm{g})}$ distributions obtained at each supra-optimal temperature were then used to produce the predicted germination curves at the different $\psi$ and supra-optimal T.

\section{Results}

In order to find the cardinal temperatures of the seed batch, Hylocereus setaceus seeds were germinated in distilled water under white light at different constant temperatures. The germinability (final germination) in the temperature range of 11 to $40{ }^{\circ} \mathrm{C}$ was relatively high in practically all the isotherms. With the exception of $40{ }^{\circ} \mathrm{C}$, in which the germinability was around $70 \%$, the final germination at the different temperatures attained values between 80 and 100\% (Figure 1a). The relative homogeneity of the seed population with regard to germination capacity allowed the germination rate indexes at the different temperatures to be compared to each other. The average germination rate increased with temperature at the range of 11 to $20^{\circ} \mathrm{C}$, and decreased above $30{ }^{\circ} \mathrm{C}$. The germination rate did not vary in the 20 to $30{ }^{\circ} \mathrm{C}$ range (Figure $1 \mathrm{~b}$ ). Thus, the effect of the PEG solutions was tested at temperatures of 11,14 and $17^{\circ} \mathrm{C}$, considered as infra-optimal, and at 34,37 and $40{ }^{\circ} \mathrm{C}$, considered as supra-optimal.

The distributions of accumulated germination percentages of Hylocereu setaceus seeds incubated in different PEG 6000 solutions show that increasing PEG concentrations (= reducing water potentials) can affect both the beginning of the germination and the germinability (Figure 2 and Table 1). At infra-optimal temperatures, germination is delayed at lower nominal water potentials, particularly at -0.2 and $-0.35 \mathrm{MPa}$. As compared to the distilled water control, germinability decreased significantly only for the seeds incubated in the $-0.35 \mathrm{MPa}$ solution at the temperatures of 14 and $17{ }^{\circ} \mathrm{C}$ (Table 1). When the seeds were imbibed in reduced $\psi$ at the supra-optimum temperature range, a delay in germination was observed relative to the seeds kept in distilled water (Figure 2), and also the final germination was inhibited in seeds incubated in $-0.35 \mathrm{MPa}$ solutions at 34,37 and $40{ }^{\circ} \mathrm{C}$, as well as in $-0.2 \mathrm{MPa}$ solution at $37^{\circ} \mathrm{C}$ (Table 1). The solid lines in the Figure 2 are based upon the $\psi_{\mathrm{b}(\mathrm{g})}$ threshold distributions predicted by the hydrotime model. In general, the lines described relatively well the distributions of the observed cumulative germinations percentage in the 0 and $-0.1 \mathrm{MPa}$ treatments, whereas the predicted values show a poor agreement with the observed ones at the nominal water potentials of -0.2 and $-0.35 \mathrm{MPa}$.

Figure 3 shows the relationship between germination rate (the reciprocal of the time to a given fraction to germinate) and $\psi$. In order to standardise the y scales some fractions (symbols in Figure 3) were omitted for seeds germinated at $17{ }^{\circ} \mathrm{C}$ in distilled water $(\psi=0 \mathrm{MPa})$. In general, the germination rate decreased with the reduction of the $\psi$, but the effect depended on the temperature. At the infra-optimum range the slope of the regression line of the germination rate on $\psi$ increases with temperature, whereas at the supra-optimal interval the slope reduces with increasing temperatures (Figure 3). At $40{ }^{\circ} \mathrm{C}$ there
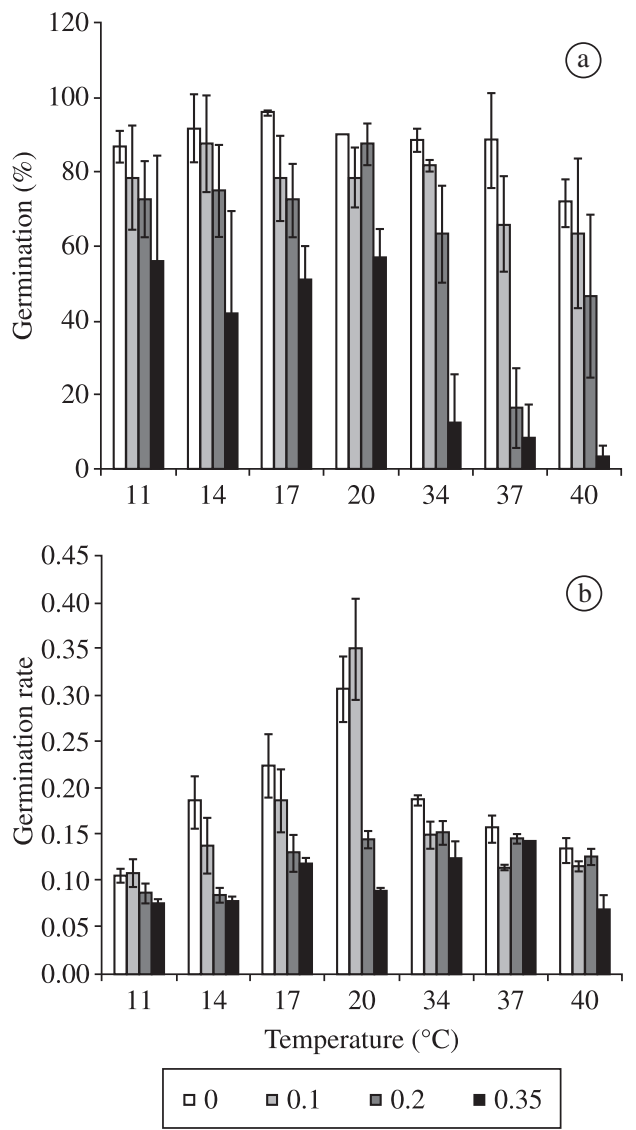

Figure 1. Dependence of temperature on germinability (a) and germination rate (b) of Hylocereus setaceus seeds incubated at 0, 0.1, 0.2 and 0.35 MPa. Data after 30 days of incubation. Germination rate taken as the reciprocal of the average germination time (days). Confidence intervals $(\alpha=0.05)$ are presented. 

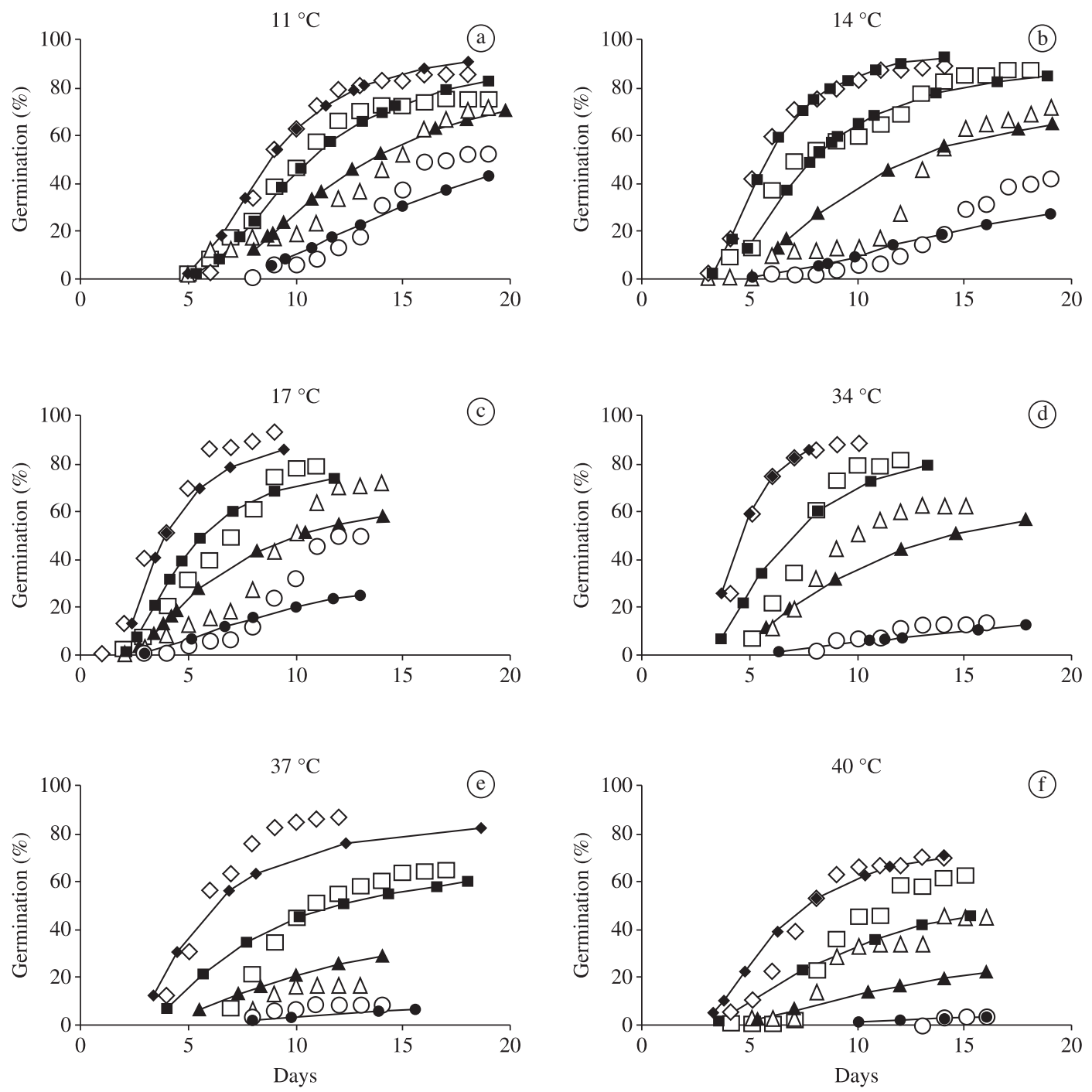

Figure 2. Cumulative distribution of germination percentages of Hylocereus setaceus seeds incubated in PEG solutions with osmotic potentials of $0 \mathrm{MPa}$ (distilled water control) $(\diamond),-0.1 \mathrm{MPa}(\square),-0.2 \mathrm{MPa}(\triangle)$ and $-0.35 \mathrm{MPa}(\circ)$ at different constant temperatures. Symbols are the actual data and lines are the predicted values by the model probit ${ }_{(\mathrm{g})}=\left[\psi-\left(\theta_{\mathrm{H}} / \mathrm{t}_{\mathrm{g}}\right)-\psi_{\mathrm{b}(50)}\right] /$ $\sigma_{\psi b}$. Parameter values are displayed in Table 2.

Table 1. Statistical comparisons amongst water potentials $(\Psi)$ and temperature treatments on the germinability of Hylocereus setaceus seeds. Letters ( $\mathrm{LSD}_{\text {Tukey }}, \alpha=0.05, \mathrm{n}=3$ ) compare germinability (final germination); small letters = horizontal comparisons; capital letters $=$ vertical comparisons.

\begin{tabular}{ccccccc}
\hline \multicolumn{7}{c}{ Temperature $\left({ }^{\circ} \mathbf{C}\right)$} \\
\hline$\Psi(\mathbf{M P a})$ & $\mathbf{1 1}$ & $\mathbf{1 4}$ & $\mathbf{1 7}$ & $\mathbf{3 4}$ & $\mathbf{3 7}$ & $\mathbf{4 0}$ \\
\hline 0.0 & $86.7 \mathrm{Aa}$ & $91.7 \mathrm{Aa}$ & $95.8 \mathrm{Aa}$ & $88.3 \mathrm{Aa}$ & $89.1 \mathrm{Aa}$ & $71.7 \mathrm{Aa}$ \\
-0.1 & $78.3 \mathrm{Aa}$ & $87.5 \mathrm{Aa}$ & $78.3 \mathrm{ABa}$ & $81.7 \mathrm{Aa}$ & $65.8 \mathrm{Aa}$ & $63.3 \mathrm{Aa}$ \\
-0.2 & $72.5 \mathrm{Aa}$ & $75.0 \mathrm{ABa}$ & $72.5 \mathrm{ABa}$ & $63.3 \mathrm{Aa}$ & $16.7 \mathrm{Bb}$ & $46.7 \mathrm{Aab}$ \\
-0.35 & $55.8 \mathrm{Aa}$ & $41.7 \mathrm{Bac}$ & $50.8 \mathrm{Bab}$ & $12.5 \mathrm{Bb}$ & $8.33 \mathrm{Bc}$ & $3.33 \mathrm{Bc}$ \\
\hline
\end{tabular}

was no relationship between the germination rate and $\psi$ since the determination coefficient was not significant.

Assuming that the germination rate of Hylocereus setaceus seeds changes linearly with temperature both at the infra and supra-optimum range, and that $\mathrm{T}_{\mathrm{b}}$ is relatively constant and independent of the water potential, the data were analysed according to the thermal time, hydrotime and hydrothermal time models. Firstly, the accumulated daily germination percentages of seeds im- 
bibed in distilled water at 11,14 and $17{ }^{\circ} \mathrm{C}$ were transformed to probit and regressed on $\log \theta_{\mathrm{g}}\left[=\left(\mathrm{T}-\mathrm{T}_{\mathrm{b}}\right) \mathrm{t}_{\mathrm{g}}\right]$, and the value of $\mathrm{T}_{\mathrm{b}}$ that produced the best fit was $7^{\circ} \mathrm{C}$, taken as the minimum temperature for the germination of $H$. setaceus seeds. In the supra-optimum temperature range the values of $\operatorname{probit}(\mathrm{g})$ were related to $\log \mathrm{T}_{\mathrm{c}(\mathrm{g})}$ $\left[=\mathrm{T}+\theta / \mathrm{t}_{\mathrm{g}}\right]$, and the best fit was obtained with $\theta=77^{\circ}$ day. The number of degrees day necessary for $50 \%$ of the seeds to germinate in the infra-optimum temperature range was $39.3^{\circ}$ day (Table 2 ), derivate from the regression line of probit $(\mathrm{g})$ on $\log \theta_{\mathrm{g}}$. In the supra-optimum

$11^{\circ} \mathrm{C}$
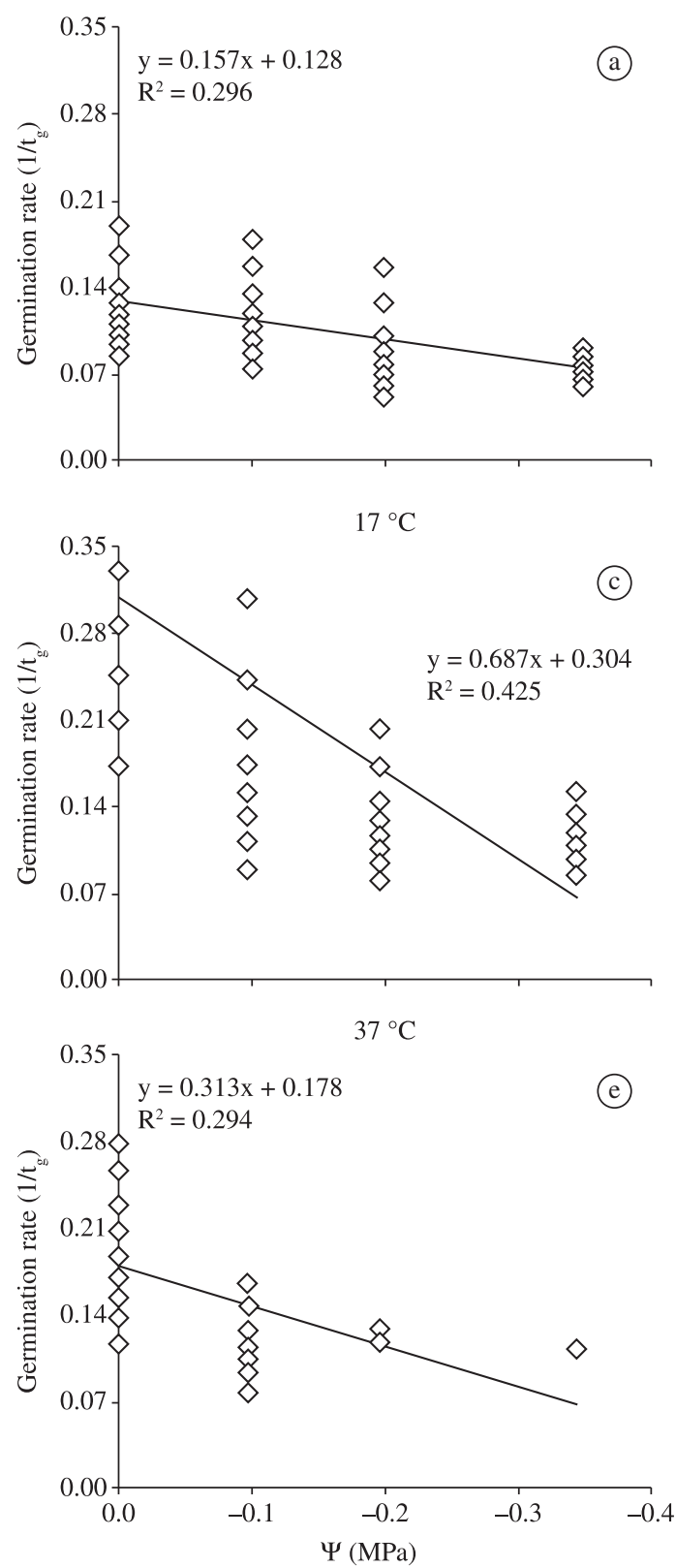

interval the value of $\theta=77$ was assumed to be constant throughout, and the limiting factor for germination would be the distribution of $\mathrm{T}_{\mathrm{c}(\mathrm{g})}$ within the population. The values of $\mathrm{T}_{\mathrm{c}(\mathrm{g})}$ derived from the relationship between probit(g) at 34,37 and $40{ }^{\circ} \mathrm{C}$ and $\mathrm{T}_{\mathrm{c}}$ varied from nearly 43.5 to $59{ }^{\circ} \mathrm{C}$, and the median $\mathrm{T}_{\mathrm{c}}\left(\mathrm{T}_{\mathrm{c}(50)}\right)$ corresponding to the fraction $50 \%$ was $49.8{ }^{\circ} \mathrm{C}$ (Table 2).

The probit transformed germination percentages of $H$. setaceus seeds incubated in different $\psi$ at each infra-optimum temperature were regressed on $\psi_{\mathrm{b}(\mathrm{g})}\left(=\psi-\left[\theta_{\mathrm{H}} / \mathrm{t}_{\mathrm{g}}\right]\right)$ and the values of $\theta_{\mathrm{H}}$ that produced the
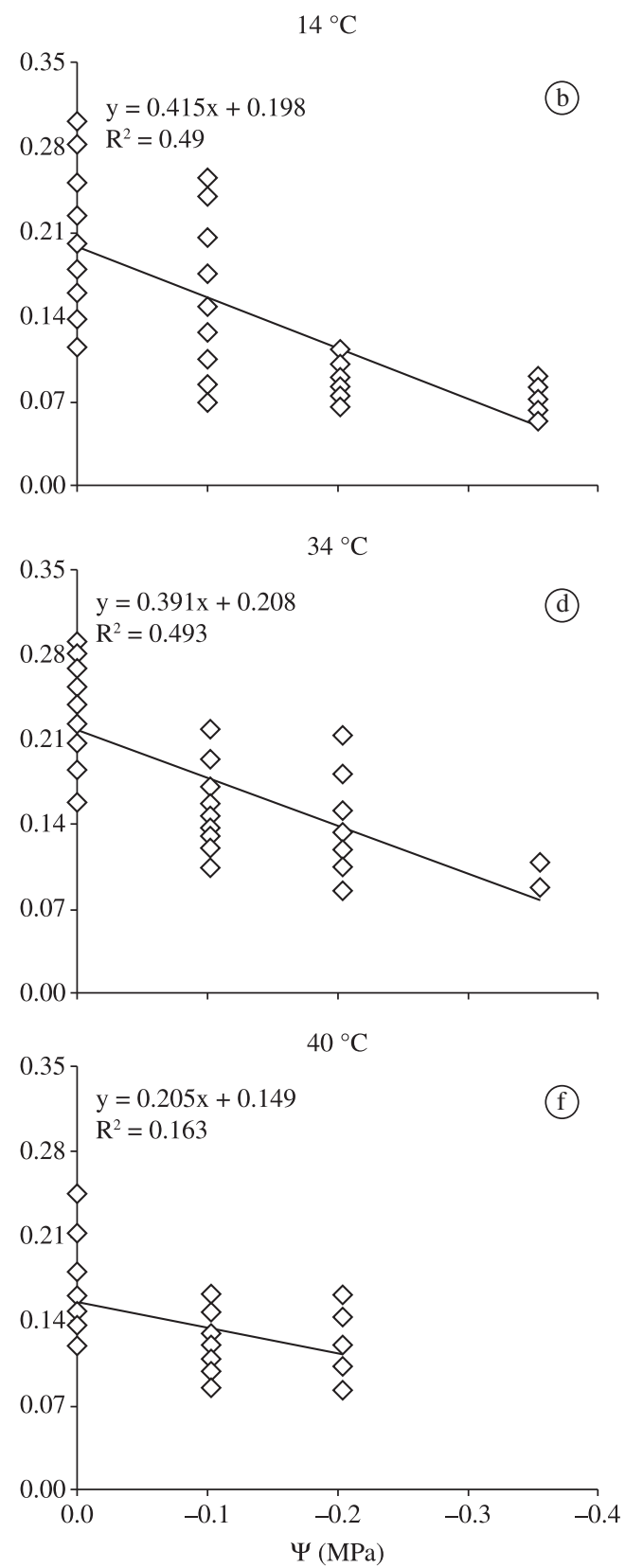

Figure 3. Relationship between seed germination rates, taken as the reciprocal of the time for germination of a given percent fraction $\mathrm{g}\left(\mathrm{t}_{\mathrm{g}}\right)$, and water potential (MPa) in Hylocereus setaceus seeds germinated at different temperatures. 
Table 2. Parameters of the germination of Hylocereus setaceus seeds at supra and infra-optimal temperatures at different water potentials $(0,-0.1 \mathrm{MPa},-0.2 \mathrm{MPa}$ and $-0.35 \mathrm{MPa})$.

\begin{tabular}{|c|c|c|c|c|c|c|}
\hline Model & $\mathbf{T}\left({ }^{\circ} \mathbf{C}\right)$ & & Par & meters & & \\
\hline Probit $_{(\mathrm{g})}=\left\{\log \left[\left(\mathrm{T}-\mathrm{T}_{\mathrm{b}}\right) \mathrm{t}_{\mathrm{g}}\right]-\log \theta_{(50)}\right\} / \sigma \theta$ & & $\theta_{(50)}\left({ }^{\circ} \mathrm{C}\right.$ day $)$ & $\mathrm{T}_{\mathrm{b}}\left({ }^{\circ} \mathrm{C}\right)$ & $\sigma \theta\left({ }^{\circ} \mathrm{C}\right)$ & & \\
\hline & $11 \rightarrow 17$ & 39.3 & 7.0 & 18.7 & & \\
\hline Probit $_{(\mathrm{g})}=\left\{\log \left[\left(\mathrm{T}+\theta / \mathrm{t}_{\mathrm{g}}\right]-\log \mathrm{T}_{\mathrm{c}(50)}\right\} / \sigma_{\mathrm{Tc}}\right.$ & & $\theta\left({ }^{\circ} \mathrm{C}\right.$ day $)$ & $\mathrm{T}_{\mathrm{c}(50)}\left({ }^{\circ} \mathrm{C}\right)$ & $\sigma_{\mathrm{Tc}}\left({ }^{\circ} \mathrm{C}\right)$ & & \\
\hline & $34 \rightarrow 40$ & 77 & 49.8 & 5.0 & & \\
\hline $\operatorname{Probit}_{(\mathrm{g})}=\left[\Psi-\left(\theta_{\mathrm{H}} / \mathrm{t}_{\mathrm{g}}\right)-\Psi_{\mathrm{b}(50)}\right] / \sigma \Psi_{\mathrm{b}}$ & & $\theta_{\mathrm{H}}(\mathrm{MPa}$ day $)$ & $\Psi_{\mathrm{b}(50)}(\mathrm{MPa})$ & $\sigma \Psi_{b}(\mathrm{MPa})$ & & \\
\hline & 11 & 5.1 & -0.58 & 0.22 & & \\
\hline & 14 & 2.1 & -0.37 & 0.15 & & \\
\hline & 17 & 1.3 & -0.33 & 0.18 & & \\
\hline & 34 & 1.3 & -0.29 & 0.11 & & \\
\hline & 37 & 1.3 & -0.21 & 0.15 & & \\
\hline & 40 & 1.3 & -0.17 & 0.14 & & \\
\hline $\operatorname{Probit}_{(\mathrm{g})}=\left\{\left[\Psi-\theta_{\mathrm{HI}} /\left(\left(\mathrm{T}-\mathrm{T}_{\mathrm{b}}\right) \mathrm{t}\right)\right]-\Psi_{\mathrm{b}(50)}\right\} / \sigma \Psi_{\mathrm{b}}$ & & $\theta_{\mathrm{HT}}\left(\mathrm{MPa}{ }^{\circ} \mathrm{C}\right.$ day $)$ & $\Psi_{\mathrm{b}(50)}(\mathrm{MPa})$ & $\sigma \Psi_{b}(\mathrm{MPa})$ & $\mathrm{T}_{\mathrm{b}}\left({ }^{\circ} \mathrm{C}\right)$ & \\
\hline & $11 \rightarrow 17$ & 14.3 & -0.38 & 0.19 & 7.0 & \\
\hline $\operatorname{Probit}_{(\mathrm{g})}=\left\{\left[\Psi-\mathrm{k}_{\mathrm{T}}\left(\mathrm{T}-\mathrm{T}_{\mathrm{o}}\right)\right]-\left(\theta_{\mathrm{H}} / \mathrm{t}_{\mathrm{g}}\right)-\Psi_{\mathrm{b}(50)}\right\} / \sigma \Psi_{\mathrm{b}}$ & & $\theta_{\mathrm{H}}(\mathrm{MPa}$ day $)$ & $\Psi_{\mathrm{b}(50)}(\mathrm{MPa})$ & $\sigma \Psi_{b}(\mathrm{MPa})$ & $\mathrm{T}_{\mathrm{o}}\left({ }^{\circ} \mathrm{C}\right)$ & $\mathrm{k}_{\mathrm{T}}\left(\mathrm{MPa} /{ }^{\circ} \mathrm{C}\right)$ \\
\hline & $34 \rightarrow 40$ & 1.3 & -0.38 & 0.13 & 29.5 & 0.021 \\
\hline
\end{tabular}
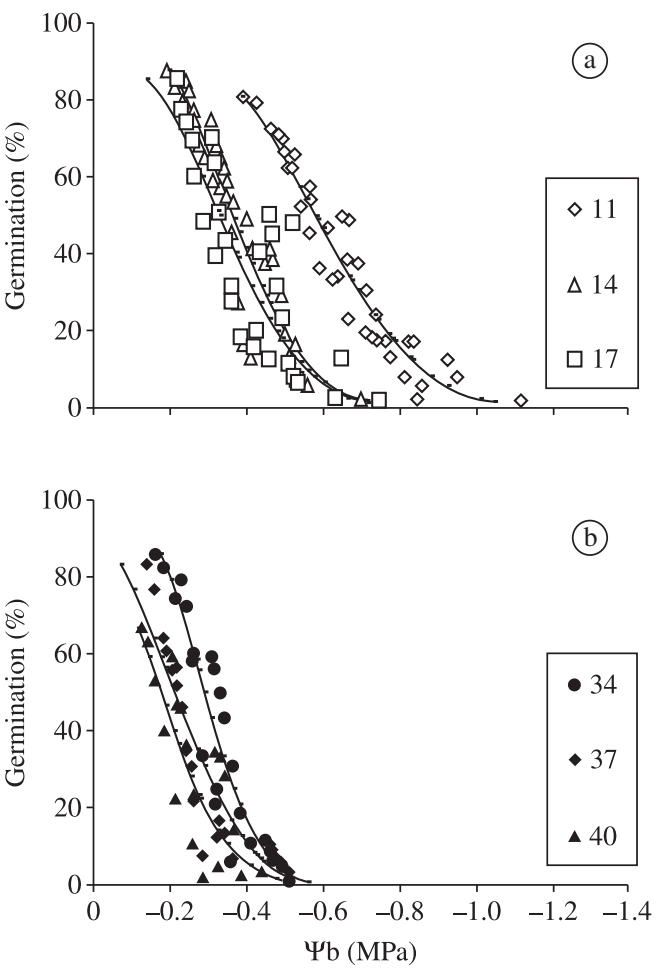

Figure 4. Relationship between $\psi_{\mathrm{b}}$ and germination (\%) of Hylocereus setaceus seeds at infra (a) and supra-optimal (b) temperatures. The solid lines are the respective normal distributions of $\psi_{\mathrm{b}}$ values among individual seeds.

best fit at each temperature are presented (Table 2). The number of $\psi$ day units decreased from $-5.1 \mathrm{MPa}$ day at the temperature of $11{ }^{\circ} \mathrm{C}$ to $-1.3 \mathrm{MPa}$ day at $17{ }^{\circ} \mathrm{C}$. In the supra-optimal temperature interval a single value of $\theta_{\mathrm{H}}(=-1.3 \mathrm{MPa}$ day $)$, predicted by the hydrothermal time supra-optimal model across $34-40{ }^{\circ} \mathrm{C}$ (Table 2), was used to fit germination data across different water potentials at each $\mathrm{T}\left(34,37\right.$ and $\left.40{ }^{\circ} \mathrm{C}\right)$. It was also observed that the values of $\psi_{\mathrm{b}(50)}$ tend to increase (become less negative) with increasing temperatures, although such variation is not pronounced throughout the thermal interval (Table 2). The distributions of $\psi_{\mathrm{b}(\mathrm{g})}$ values corresponding to the actual daily germination percentages are presented as symbols in Figure 4. The solid lines are the respective normal distributions of $\psi_{b}$ values both in the infra-optimum (Figure 4a) and supra-optimum (Figure 4b) interval of T. The curves in the infra-optimum range (Figure 4a) appear to be less inclined than curves in the supra-optimum interval (Figure 4b), as well as the standard deviations of $\psi_{\mathrm{b}(\mathrm{g})}$ at the infra-optimal temperatures tended to be higher as compared to that observed at supra-optimal ones (Table 2). It is also observed that the values of $\psi_{\mathrm{b}(\mathrm{g})}$ decrease (became more negative) the lower the percent fraction of germinated seeds, that is, the "faster" the seed the lower the value of $\psi_{\mathrm{b}(\mathrm{g})}$ (Figure 4).

\section{Discussion}

In the present work we used Hylocereus setaceus seeds stored for about 22 months, and the germinability of the batch was similar to that of newly collected seeds (Simão et al., 2007), suggesting that the seed viability remains unaltered for at least this period of storage. De La Barrera and Nobel (2003) reported that the final germination of Stenocereus gueretaroensis seeds was maximal for seeds stored between 12 and 28 months and declined after 40 months of storage. The authors observe that the presence of seed dormancy can account for relatively low germinability of recently collected $S$. gueretaroensis seeds. The germinability of $H$. setaceus seeds at optimal conditions apparently does not vary over a period of approximately two years from the seed collection. Otherwise, stored $H$. setaceus seeds appear to germinate 
in a wider temperature range than newly collected ones (see below), suggesting that the dispersed seeds present relative primary dormancy (Labouriau, 1983).

Hylocereus setaceus seeds are capable of germinating in a relatively wide range of temperatures, with the final germination attaining values between 70 and $100 \%$ in the interval of 11 to $40{ }^{\circ} \mathrm{C}$. The germination of $H$. setaceus was rate limited from 11 to $20^{\circ} \mathrm{C}$ interval and beyond 30 until $40{ }^{\circ} \mathrm{C}$, since in such thermal intervals the germination rate respectively shifts positively and negatively with temperature. These preliminary results are in accordance with the results obtained by Simão et al. (2007) with newly collected $H$. setaceus seeds. Such authors reported that the germinability of the species is maximal in the range of 15 to $40{ }^{\circ} \mathrm{C}$ and the germination rate increases with temperature in the range of 10 to $25^{\circ} \mathrm{C}$ and decreases at temperatures above $30{ }^{\circ} \mathrm{C}$. Otherwise, the storage period apparently influenced both the germinability and germination rate response to temperature, since the germinability of newly collected seeds at $10 \pm 1{ }^{\circ} \mathrm{C}$ was around 5\% (Simão et al., 2007) whereas the average germinability at $11 \pm 1{ }^{\circ} \mathrm{C}$ reported here was $87 \%$, and the germination rate at $20{ }^{\circ} \mathrm{C}$ was higher in stored seeds than in newly collected ones. Thus, the temperature of $20{ }^{\circ} \mathrm{C}$ was taken as infra-optimal by Simão et al. (2007) and optimal according to the results herein reported. The minimum or base temperature for the germination of $H$. setaceus found in this work $\left(7^{\circ} \mathrm{C}\right)$ is within the range of 5 to $10^{\circ} \mathrm{C}$ predicted by Simão et al. (2007), and the median ceiling temperature (corresponding to the fraction $50 \%$ ) was $49.8{ }^{\circ} \mathrm{C}$, that is within the range of $\mathrm{T}_{\mathrm{c}}(45$ to $50{ }^{\circ} \mathrm{C}$ ) expected by those authors. From the isothermal assays with $H$. setaceus seeds imbibed in distilled water it is possible to conclude that its germination is optimal in temperatures ranging from 20 to $30{ }^{\circ} \mathrm{C}$, therefore within the optimum range $\left(17\right.$ to $34{ }^{\circ} \mathrm{C}$ ) described for the germination of many other cactacean, with optimal values frequently around $25{ }^{\circ} \mathrm{C}$ (Rojas-Arechiga and Vazquez-Yanes, 2000). Dau and Labouriau (1974) reported an optimum temperature of $33{ }^{\circ} \mathrm{C}$ for the germination of Pereskia aculeata, a cactaceae of fairly common occurrence in the Restinga vegetation, but its germinability drops to zero at $39^{\circ} \mathrm{C}$, whereas $H$. setaceus can germinate at temperatures upper than $40{ }^{\circ} \mathrm{C}$ (Simão et al. 2007). The infra-optimum temperatures for the germination of $\mathrm{H}$. setaceus are within the range of 7 to $20^{\circ} \mathrm{C}$, and the supra-optimal range is beyond $30^{\circ} \mathrm{C}$.

The germination of $H$. setaceus seeds, as many other species, is sensitive to decreasing values of $\Psi$ in the medium, and both the germinability and the germination rate shift negatively with the reduction of $\Psi$. In general, the germinability at nominal $\Psi$ of $-0.1 \mathrm{MPa}$ and $-0.2 \mathrm{MPa}$ did not differ statistically from that in distilled water $(\Psi=0)$, but it was inhibited at $-0.35 \mathrm{MPa}$. These results are similar to that obtained by Ramirez-Padilla and Valverde (2005) with three columnar cactus (Neobuxbaumia mazcalaensis, N. tetetzo and $N$. macrocephala). The authors reported that a $\Psi$ of
$-0.4 \mathrm{MPa}$ inhibited the germinability whereas the germination of seeds incubated in -0.1 MPa PEG solutions did not differ from the distilled water control. Otherwise, the effect of the $-0.35 \mathrm{MPa}$ treatment on $H$. setaceus seeds seems to be more pronounced in seeds kept in supra-optimal temperatures, since the lowest values of germinability were observed for seeds incubated at $-0.35 \mathrm{MPa}$ at the temperatures of 34,37 and $40{ }^{\circ} \mathrm{C}$. The germination rate of $H$. setaceus seeds tends to decrease at lower water potentials, and the rate of reduction (the slope of the linear regression of germination rate on $\Psi$ ) changed with temperature. The results suggest that the slope is greater toward the optimal temperature range and diminishes toward both minimum and maximal temperatures. Indeed, at the supra-optimal temperature of $40{ }^{\circ} \mathrm{C}$ no significant relationship could be found between germination rate of $H$. setaceus seeds and water potentials of 0 to $-0.2 \mathrm{MPa}$. $H$. setaceus appears to be less sensitive to relatively low water potential than Ficus aurea, a hemiepiphytic species, which germination is almost nullified in substrate $\Psi$ of $-1.5 \mathrm{MPa}$ and lower (Swagel et al., 1997). The seeds of that hemiepiphytic species are deposited by frugivores in humus-filled cavities on potential host trees, and the moisture reaching the humic substrate in leaf bases is retained. According to Swagel et al. (1997) palm leaf base humus potentially holds four times as much water as does open soil, and the moisture content of this humic substrate is $15-16 \%$ by mass, translating to a $\Psi$ ranging from -1.0 to $-1.1 \mathrm{MPa}$. Otherwise, the stem water potential in Quercus agrifolia ranged from -0.25 to $-3.1 \mathrm{MPa}$, and was negatively correlated with insulation and the percent of the tree canopy exposed to direct overhead sunlight (Swiecki and Bernhardt, 2002). Seeds of H. setaceus were not found germinating at the soil surface in the seed collection areas, where the seedlings can be subjected to death during an eventually rapid drying of the substrate. Moreira (unpublished data), working with a distrophic red latossol with loamy texture, reported that a soil water potential of $-0.3 \mathrm{MPa}$ corresponds to a moisture content (\% in dry soil) of $25.4 \%$, which is between the permanent wilting point $(-1.5 \mathrm{MPa} ; 22.1 \%$ moisture $)$ and field capacity ( $-0.03 \mathrm{MPa} ; 31.1 \%$ moisture). Thus, regarding this soil, a decrease of the soil moisture as much as 5-6\% may be enough to delay and/or inhibits the germination of $H$. setaceus seeds at or near the soil surface. Thus, it is possible that, similar to what occurs in Ficus aurea, the germination and seedling establishment only occur on the trunk of the tree host, which provide a more favorable micro-environment with respect to temperature and moisture.

At the supra-optimum temperature range we followed the hypothesis of Alvarado and Bradford (2002) according to which the decrease of both the germination rate and percentage at these temperatures is due to an increase (less negative values) in the $\Psi_{b(g)}$ thresholds for germination, allowing the hydrothermal time model to be extended to the supra-optimal interval. Indeed the values of $\Psi_{b(50)}$ derived from the relationship between 
the probits of the accumulated daily germination percentages of Hylocereus setaceus and $\Psi-\left[\theta_{\mathrm{H}} / \mathrm{t}_{\mathrm{g}}\right]$ shift to zero with increasing temperatures, although the median $\Psi_{\mathrm{b}}$ values did not differ significantly to each other within the respective temperature range (if infra or supra-optimum), probably due to relatively high variance of the data. These results differ partially from that obtained by Alvarado and Bradford (2002) with Solanum tuberosum seeds, in which the median $\Psi_{b}$ were relatively constant in the infra-optimal range of $\mathrm{T}$, whereas in the supraoptimum range the $\Psi_{\mathrm{b}}$ values became more positive with temperature. These authors concluded that in the infra-optimal temperature interval, in which $\Psi_{\mathrm{b}(50)}$ and $\sigma_{\Psi \mathrm{b}}$ are relatively unchanged among $\mathrm{T}$, the decrease of $\mathrm{t}_{\mathrm{g}}$ is caused by increase of the difference between $\mathrm{T}$ and $\stackrel{\mathrm{T}}{\mathrm{b}}_{\mathrm{b}}$ and is reflected in decreasing $\theta_{\mathrm{H}}$ values as temperature rises. This feature was observed also in H. setaceus, since the hydrotime constant dropped from 5.1 MPa day at $11{ }^{\circ} \mathrm{C}$ to $1.3 \mathrm{MPa}$ day at $17^{\circ} \mathrm{C}$. Otherwise, a question remains whether the sensitivity (represented by the variation of $\left.\Psi_{b(g)}\right)$ of $H$. setaceus seeds to $\Psi$ does not change with temperature at the infra-optimum range of $\mathrm{T}$, taking into account the relatively discrepancy among the values of $\sigma_{\psi \mathrm{b}}$ at $11{ }^{\circ} \mathrm{C}$ and the other two infra-optimal temperatures tested $\left(14\right.$ and $\left.17{ }^{\circ} \mathrm{C}\right)$. The standard error $(\sigma)$ reflects the "spread" of the distributions of the germination times, and the smaller the value of $\sigma$, the greater is the effect on germination of any change in dose (Finney, 1971). Contrary to what occurs in the infra-optimum range, at supra-optimal temperatures there is no accumulation of thermal time, and $t_{g}$ (which is inversely related to the difference between $\mathrm{T}_{c}$ and $\mathrm{T}$ ) increases with increasing temperatures (Alvarado and Bradford, 2002). If $\Psi_{\mathrm{b}(\mathrm{g})}$ becomes less negative with $\mathrm{T}$, then the difference between $\Psi$ and $\Psi_{\mathrm{b}(\mathrm{g})}$ decreases, but this decrease is compensated by the increase of $t_{g}$ due to the effect of the supra optimal $\mathrm{T}$, thus $\theta_{\mathrm{H}}$ tends to be constant. A value of $\theta_{\mathrm{H}}$ equal to $-1.3 \mathrm{MPa}$ day was obtained for $H$. setaceus seeds incubated in different water potentials at the supra-optimum temperature range. Thus $H$. setaceus seeds may require $-1.3 \mathrm{MPa}$ day to complete germination at any supra-optimal temperature, and the inverse of $\theta_{\mathrm{H}}$ indicates the rate of progress toward radicle protrusion per unit of difference between $\Psi$ and $\Psi_{\mathrm{b}(\mathrm{g})}$ (Bradford, 1995). At the supra-optimum range, the values of $\Psi_{b(g)}$ for $H$. setaceus seeds shift positively from $-0.29 \mathrm{MPa}$, at $34{ }^{\circ} \mathrm{C}$, to $-0.17 \mathrm{MPa}$ at $40{ }^{\circ} \mathrm{C}$, and such variation reflects in the relatively greater effect of low $\Psi$ (particularly at $-0.35 \mathrm{MPa}$ ) on germination in that temperature range. In general, the capacity of the model to predict the germination time courses of $H$. setaceus seeds depended on the temperature and water potential. Indeed a relatively poor agreement between the actual and the expected curves was observed in some cases, but the roughly better description of the germination time courses was observed for the water potentials of 0 and $-0.1 \mathrm{MPa}$. The model assumes a common value of $\mathrm{T}_{\mathrm{b}}$ for all fractions of the seed population, and that $\mathrm{T}_{\mathrm{b}}$ is independent of $\Psi$ and
$\Psi_{\mathrm{b}(\mathrm{g})}$ is independent of $\mathrm{T}$, which may not always be the case (Bradford, 1995). Thus, the results presented here suggest that in $H$. setaceus seeds $\mathrm{T}_{\mathrm{b}}$ may not be independent of $\Psi$ and that $\Psi_{b(g)}$ may change as a function of temperature at the infra-otimum temperature range. However, further assays are needed in order to test the constancy and independence of $\mathrm{T}_{\mathrm{b}}$ and $\Psi_{\mathrm{b}(\mathrm{g})}$ in the seed germination of this species.

Acknowledgements - E.S. was supported by FAPESP during this research and M.T. and V.J.M.C are CNPq Research fellows.

\section{References}

ALVARADO, V. and BRADFORD, KJ., 2002. A hydrothermal time model explains the cardinal temperatures for seed germination. Plan, Cell and Environment, vol. 25, no. 8, p. 1061-1069.

BRADFORD, K., 1995. Water relations in seed germination. In KIGEL, J. and GALILI, G. SeedDevelopment and Germination. New York: Marcel Dekker Inc. p. 351-396.

BRADFORD, KJ. and SOMASCO, OA., 1994. Water relations of lettuce seed thermoinhibition. I. Priming and endosperm effects on base water potential. Seed Science Research, vol. 4, no. 1 , p. 1-10.

BRADFORD, KJ., 1997. The hydrotime concept in seed germination and dormancy. In ELLIS, RH., BLACK, M., MURDOCH, AJ. and HONG, TD. Basic and Applied Aspects of Seed Biology. Boston: Kluwer Academic Publishers. p. 349-360.

BRADFORD, KJ. and STILL, DW., 2004. Applications of hydrotime analysis in seed testing. Seed Technology, vol. 26, no. 1, p. $75-85$.

BRITTONN, NL. and ROSE, JN., 1937. The Cactaceae: descriptions and illustrations of plants of the Cactus family. New York: Dover Publications, Inc.

DAU, L. and LABOURIAU, LG., 1974. Temperature control of seed germination in Pereskia aculeate Mill. Anais da Academia Brasileira de Ciências, vol. 46, no. 2, p. 311-322.

DE LA BARRERA, E. and NOBEL, PS., 2003. Physiological ecology of seed germination for the columnar cactus Stenocereus queretaroensis. Journal of Arid Environments, vol. 53, no. 3, p. 297-306.

DONOHUE, K., 2005. Seeds and seasons: interpreting germination timing in the field. Seed Science Research, vol. 15, no. 3 , p. 175-187.

DUMUR, D., PILBEAM, CJ. and CRAIGON, J., 1990. Use of the Weibull Function to Calculate Cardinal Temperatures in Faba Bean. Journal of Experimental Botany, vol. 41, no. 11, p. 1423-1430.

FINNEY, DJ., 1971. Probit Analysis. $3^{\text {td }}$ Ed. Cambridge: Cambridge University Press. 350p.

FLORES, J. and BRIONES, O., 2001. Plant life-form and germination in a Mexican inter-tropical desert: effects of soil water potential and temperature. Journal of Arid Environments, vol. 47, no. 4, p. 485-497.

GARCIA-HUIDOBRO, J., MONTEITH, JL. and SQUIRE, GR., 1982. Time, temperature and germination of pearl millet 
(Pennisetum typhoides) I. Constant temperature. Journal of Experimental Botany, vol. 33, no. 133, p. 288-296.

GUMMERSON, RJ., 1986. The effect of Constant temperatures and osmotic potentials on the germination of sugar beet. Journal of Experimental Botany, vol. 37, no. 179, p. 729-741.

KLOS, KLE. and BRUMMER, EC., 2000. Response of six alfafa population to selection under laboratory conditions for germination and seedling vigor at low temperatures. Crop Science, vol. 40, no. 5, p. 959-964.

LABOURIAU, LG., 1983. A Germinação das Sementes. Washington, DC: Secretaria Geral da Organização dos Estados Americanos.

LABOURIAU, LG. and AGUDO, M., 1987. On the physiology of seed germination in Salvia hispanica L. I. Temperature effects. Anais da Academia Brasileira de Ciências, vol. 59, no. 1, p. 37-56.

RAMÍREZ-PADILLA, CA. and VALVERDE, L., 2005. Germination responses of three congeneric cactus species (Neobuxbaumia) with differing degrees of rarity. Journal of Arid Environments, vol. 61, no. 2, p. 333-343.

ROJAS-ARÉCHIGA, M. and VÁZQUEZ-YANES, C., 2000. Cactus seed germination: a review. Journal of Arid Environments, vol. 44 , no. 1 , p. 85-104.
SIMÃO, E., SOCOLOWSKI, F. and TAKAKI, M., 2007. The epiphytic Cactaceae Hylocereus setaceus (Salm-Dick ex DC) Ralf Bauer seed germination is controlled by light and temperature. Brazilian Archives of Biology and Technology, vol. 50, no. 4, p. 655-662.

SWAGEL, EN., BERNHARD, A., VAN, H. and ELLMORE, GS., 1997. Substrate water potential constraints on germination of the strangler fig Ficus aurea (Moraceae). American Journal of Botany, vol. 84, no. 5, p. 716-722.

SWIECKI, TJ. and BERNHARDT, E., 2002. Evaluation of stem water potential and other tree and stand variables as risk factors for Phytophthora ramorum canker development in coast live oak. In Proceedings of the Fifth Symposium on Oak Woodlands: oaks in California's challenging landscape. Albany, CA: Pacific Southwest Research Station, Forest Service, U.S. Department of Agriculture. p. 787-798.

VILLELA, FA., DONI FILHO, L. and SEQUEIRA, EL., 1991. Tabela de potencial osmótico em função da concentração de polietileno glicol 6000 e da temperatura. Pesquisa Agropecuária Brasileira, vol. 26, no. 11/12, p. 1957-1968.

WASHITANI, I., 1985. Germination-rate dependence on temperature of Geranium carolinianum seeds. Journal of Experimental Botany, vol. 36, no. 163, p. 330-337. 